\title{
Physio-Chemical Resistance Mechanism of Sorghum Genotypes against Shoot Fly (Atherigona soccata) (Rondani)
}

\author{
S.P. Patil* and A.S. Bagde \\ Department of Agriculture Entomology, College of Agriculture, \\ Kolhapur - 416 004, Maharashtra, India \\ *Corresponding author
}

\section{A B S T R A C T}

\section{Keywords}

Sorghum shoot fly, Atherigona soccata

(Rondani), Host plant resistance (HPR).

\section{Article Info}

Accepted:

26 August 2017

Available Online:

10 September 2017
Sorghum shoot fly (Atherigona soccata) is an important pest of sorghum and host plant (HPR) is one of the important features for minimizing losses. Resistance against shoot fly in sorghum with governed by the physical and chemical contribute. Eleven sorghum genotypes were evaluated under the field condition for their reaction to shoot fly at Agronomy field, college of agriculture Kolhapur in Rabi 2016-17. Field studies showed that the genotypes viz. IS 2312, IS 2215 and IS 18551 were promising to shoot fly resistance, on the basis of morphophysiological traits such as plant height, leaf glossiness, trichome density, leaf surface wetness and biochemical traits such as moisture content, soluble proteins, total sugars, total chlorophyll content. While genotypes DJ 6514 and Amruta were estimated as susceptible checks.

\section{Introduction}

Sorghum (Sorghum bicolor (L.) Monech) is the fifth most important cereal crop worldwide after wheat, rice, maize and barley (FAO, 2011). In Maharashtra, sorghum is being grown on 5.50 million hectares and production is 6.05 million tonnes. sorghum shoot fly, Atherigona soccata Rondani (Order- Diptera, Family- Muscidae) is the most destructive one and causes severe damage in the early i.e. seedling stage and last up to 4 weeks causing severe reduction in plant population thereby causing heavy yield losses. The maggot crawls to the plant whorl and then moves downward between the fold of young leaves till they reach the growing point. It cuts the growing tip and feeds on the decaying leaf tissues, which results in dead heart formation. Host plant resistance (HPR) is the most important component of integrated pest management (IPM) in sorghum. It does not involve any extra cost or other methods of pest control. Reduction in pest population through HPR can also enhance the effectiveness of natural enemies and reduce the need of pesticides (Sharma et al., 1993).

\section{Materials and Methods}

The experimental material consisted of a diverse array of 11 genotypes comprising IS 29923, IS 18360, IS 27204, RSSH 18, RSSH 50, Swarna, three resistant checks viz., IS 18551, IS 2205, IS 2312 and a susceptible checks i.e. DJ 6514 and Amruta. The 
experiment was conducted in the statistically randomized block (RBD) with three replications. Breeding lines were sown in Rabi season.

\section{Characterization of sorghum genotypes for morphological traits}

Data were recorded on plant height, leaf glossiness, trichome density and leaf surface wetness. Five seedling of each entry were selected at random and observations were recorded on seedling height on $14 \mathrm{DAE}$. The height of seedling was measured from soil surface to the opening of whorl and average height per seedling was calculated at each stage. Leaf glossiness (plants with pale green, shiny, narrow and erect leaves) was evaluated with 1 to 5 rating at $14 \mathrm{DAE}$ in the early morning hours when there was maximum reflection of light from the leaf surface (Sharma and Nwanze, 1997).

Total number trichomes were counted in microscopic fields selected at random and expressed the trichome density as number per square millimeter at 14 DAE (Sharma and Nwanze 1997). For the assessment of leaf surface wetness, seedlings (12 DAE) were examined between 6.30 and 8.30 morning hours by excising the central unfolded leaf and spreading it under a binocular microscope. The leaf surface wetness was assessed with 1-5 scale.

\section{Biochemical composition of sorghum genotypes}

Biochemical analysis for moisture content, soluble proteins, total sugars and total chlorophyll content was estimated at 14 DAE. For moisture content the seedlings were then kept in an oven at $60^{\circ} \mathrm{C}$ for three days. Weight of the oven dried material was recorded after three days. Soluble proteins were estimated by Folin-Lowry method. Total soluble sugar was determined as per the method given by
Dubois et al., (1956). Chlorophyll was extracted from leaves $(0.5 \mathrm{gm})$ with $50 \mathrm{ml}$ of $80 \%$ acetone and measuring absorbance of the solution at 645 and $663 \mathrm{~nm}$ using the method of Arnon (1949).

\section{Results and Discussion}

Morphological characteristics of different sorghum genotypes in relation to expression of resistance to shoot fly

The maximum height was recorded in IS 2312 $(23.97 \mathrm{~cm})$ and minimum height was recorded in susceptible check, DJ $6514(14.85 \mathrm{~cm})$. The entries having more seedling height were observed to be less susceptible to shoot fly infestation than the entries having lower seedling height. Similar results were recorded by Singh et al., (1989), Jayanthi et al., (1999), Nadeem et al., (2005) and Balikai (2011).

The resistant check, IS 18551 recorded minimum score of leaf glossiness (1.00). However, susceptible check, DJ 6514 recorded maximum score of leaf glossiness (4.55) which indicated non-glossiness of leaf. Similar results were recorded by Jadhav et al., (1986), Dhillon et al., (2005 a,b; 2006 a), Patil et al., (2006) and Chikkarugi and Balikai (2011). Maximum number of trichomes were observed in resistant check, IS 18551 (23.68) which was significantly maximum than rest of the genotypes. The susceptible check, DJ $6514(0.00)$ recorded lowest number of trichome. Similar results were reported by Maiti et al., (1980), Jadhav et al., (1986), Sree et al., (1992) and Taneja and Maiti (1992).. The resistant check, IS 18551 recorded minimum leaf surface wetness score (1.00) which was at par with other resistant check $v i z$. , IS 2312 (1.22), IS 2205 (1.38), IS 29923 (1.84), IS 18360 (1.86) and IS 27204 (1.98). Similar results were recorded by Nwanze $e t$ al., (1990a), Nwanze et al., (1991), Dhillon et al., (2005b, 2006), Patil et al., (2006), Chikkarugi and Balikai (2011) (Table 1). 
Table.1 Morphological characteristics of sorghum genotypes for resistance to sorghum shoot fly

\begin{tabular}{|c|c|c|c|c|}
\hline Genotype & $\begin{array}{c}\text { Plant height } \\
(\mathbf{c m})\end{array}$ & Leaf glossiness & $\begin{array}{c}\text { Trichome } \\
\text { density }\end{array}$ & $\begin{array}{c}\text { Leaf surface } \\
\text { wetness }\end{array}$ \\
\hline IS 29923 & 11.59 & 2.16 & $10.12(3.84)^{*}$ & 1.84 \\
\hline IS 18360 & 11.52 & 2.11 & $16.88(4.17)$ & 1.86 \\
\hline IS 27204 & 11.89 & 2.09 & $14.23(3.84)$ & 1.98 \\
\hline IS 18551(RC) & 11.85 & 1.00 & $23.68(4.92)$ & 1.00 \\
\hline IS 2205 (RC) & 12.74 & 1.42 & $16.89(4.17)$ & 1.38 \\
\hline IS 2312 (RC) & 11.96 & 2.02 & $17.27(4.22)$ & 1.22 \\
\hline RSSH 18 & 10.71 & 2.20 & $4.52(2.24)$ & 2.94 \\
\hline RSSH 50 & 10.96 & 2.11 & $4.22(2.18)$ & 2.92 \\
\hline Swarna & 11.07 & 2.64 & $9.28(3.13)$ & 2.84 \\
\hline DJ 6514 (SC) & 7.85 & 4.55 & $0.00(0.71)$ & 4.40 \\
\hline Amruta (SC) & 10.14 & 2.75 & $4.56(2.22)$ & 3.93 \\
\hline S.E.土 & 0.5084 & 0.0800 & 0.0707 & 0.0633 \\
\hline C.D. at 5 \% & 1.49 & 0.2361 & 0.2085 & 0.1868 \\
\hline
\end{tabular}

RC: Resistant check; SC: Susceptible check

*Figures in parentheses are arcsin transformed values

Table.2 Biochemical constituents at seedling stage in different genotypes of sorghum

\begin{tabular}{|c|c|c|c|c|}
\hline Genotype & $\begin{array}{c}\text { Moisture } \\
\text { content }(\boldsymbol{\%})\end{array}$ & $\begin{array}{c}\text { Soluble } \\
\text { proteins }(\boldsymbol{\%})\end{array}$ & $\begin{array}{c}\text { Total sugars } \\
(\boldsymbol{\%})\end{array}$ & $\begin{array}{c}\text { Total chlorophyll } \\
\text { content }\end{array}$ \\
\hline IS 29923 & 81.45 & 0.12 & 0.53 & 1.78 \\
\hline IS 18360 & 85.73 & 0.13 & 0.61 & 1.77 \\
\hline IS 27204 & 85.71 & 0.15 & 0.67 & 1.76 \\
\hline IS 18551(RC) & 86.17 & 0.13 & 0.43 & 1.73 \\
\hline IS 2205 (RC) & 83.86 & 0.14 & 0.48 & 1.75 \\
\hline IS 2312 (RC) & 83.77 & 0.14 & 0.47 & 1.72 \\
\hline RSSH 18 & 87.38 & 0.18 & 0.64 & 1.87 \\
\hline RSSH 50 & 84.65 & 0.17 & 0.68 & 1.89 \\
\hline Swarna & 85.73 & 0.16 & 0.84 & 1.93 \\
\hline DJ 6514 (SC) & 90.39 & 0.16 & 0.97 & 2.14 \\
\hline Amruta (SC) & 87.70 & 0.17 & 0.85 & 2.08 \\
\hline S.E.土 & 1.3311 & 0.0035 & 0.0145 & 0.038 \\
\hline C.D. at 5 \% & 3.94 & 0.0103 & 0.0427 & 0.113 \\
\hline
\end{tabular}

RC: Resistant check; SC: Susceptible check

\section{Biochemical composition in relation to expression of resistance to shoot fly}

The minimum moisture content was found in the genotype, Swarna ( 81.45 per cent), which was at par with the rest of the genotypes except RSSH 18 (87.38), RSSH (86.17),
Amruta (87.70) and DJ 6514 (90.39). The maximum moisture content was estimated in susceptible check, DJ 6514 (90.39 per cent) and it was significantly more than other genotypes. Singh et al., (2004) reported that there is no relationship between moisture content of sorghum seedlings and shoot fly 
resistance. Rao and Panwar (2002) reported that maize genotypes resistance to stem borer, Chilo partellus (Swin.) have low moisture content. The lowest soluble protein was found in genotype IS 29923 (0.12 per cent). However, it was at par with the genotypes viz., IS 18360, IS 27204, IS 18551, IS 2205 and IS 2312.Bhise et al., (1996a) reported that the susceptible check, CSH 1 had the highest protein content, whereas the resistant variety, IS 5490 had the lower protein content. The minimum sugar per cent was recorded in the genotype, IS 18551 (0.43 per cent). Nevertheless, it was at par with the genotype, IS 2312 (Table 2). The maximum percent sugar was noticed in the susceptible check, DJ 6514 (0.97per cent), which was significantly less than the rest of the genotype. Total sugars content have earlier been reported to be positively associated with susceptibility to stem borer (Kabre and Ghorpade, 1999) and shoot fly (Kamatar et al., 2003; Singh et al., 2004). The chlorophyll content ranged from 1.72 to $2.14 \mathrm{mg}$ per gm. The minimum chlorophyll content was found in resistant check, IS 2312. The maximum chlorophyll content was estimated in susceptible check, DJ 6514 (2.14 $\mathrm{mg}$ per gm) and it was significantly more than the rest of the entries.

\section{References}

Arnon, D.I., 1949. Copper enzymes in isolated chloroplast polyphenoloxidase in Beta vulgaris. Plant Physiol. 24: 115.

Balikai, R.A., 2011. Effect of different dates of sowing on shoot fly incidence and grain yield of sorghum. Insect Environ, 5 (2): 54-55.

Bhise, H.T., B.B. Desai and U.D. Chavan. 1996a. Assessment some biochemical parameters responsible for shoot fly resistance in sorghum. J. Maharashtra agric. Univ., 21(1):127-129.

Chikkarugi, N.M., and Balikai, R.A., 2011.
Response of sorghum genotypes in shoot pest nursery to major pest. Research J. Agril. Scie, 2(1): 21-25.

Dhillon, M.K., Sharma H.C., and B.V.S. Reddy. 2005b. Agronomic characteristics of different cytoplasmic male sterility system and their reaction to the sorghum shoot fly, Atherigona soccata. ISMN, 46:52-55.

Dhillon, M.K., Sharma H.C., Reddy B.V.S., Ram Singh, Naresh J.S. and Zhu Kai. 2005a. Relative susceptibility of different male-sterility cytoplasms in sorghum to shoot fly, Atherigona soccata. Euphytica, 144: 275-283.

Dhillon, M.K., Sharma, H.C. and B.V.S., Ram Singh., and Naresh J.S. 2006b. Inheritances of resistance to sorghum shoot fly, Atherigona soccata. Crop science, 46: 1377-1383.

Dubois, K.M., K.A. Grilles. J.K. Hamilton, P.A. Robers and F. Smith. 1956. Calorimetric methods for determination of sugars and related substances. Annal Chem., 28: 350-356.

F. A. O., 2011. FAOSTAT. http: // faostat.fao.org

Jadhav, S.S., U.N. Mote and D. R. Bapat 1986. Biophysical plant characters contributing to shoot fly resistance. Sorghum Newsletter, 29:70-71.

Jayanthi, P.D., K., Reddy B.V.S., Gour T.B. and Reddy D.D.R. 1999. Genetics of glossy and trichome characters in sorghum hybrids of cytoplasmic male sterile lines. Journal Maharashtra Agricultural Universities, 24: 251-256.

Kamatar, M.Y., Salimath P.M., Ravi Kumar R.L. and Swamy Rao T. 2003. Heterosis for biochemical traits governing resistance to shoot fly in sorghum [Sorghum bicolor (L) Moench]. Indian Journal of Genetics, 63: 124-127.

Maiti, R.K., Bidinger, K.V. Seshu Reddy, P. Gibson and J.C. Davies. 1980. Nature and occurrence of trichomes in sorghum 
lines with resistance to the sorghum shoot fly. Joint Progress Report of Sorghum Physiology/Sorghum Entomology, Vol. 3, ICRASAT, Patancheru.

Nadeem, M.H., Sadaqat, A.H. and Khan, I.H., 2005. Genetic potential of high forage yielding sorghum $\mathrm{x}$ sudangrass hybrids for resistance to stem borer (Chilo partellus) and shoot fly (Atherigona soccata). Pak. Entomol. Vol. 27:57-62.

Nwanze, K.F., R.J. Pring, P.S. Sree, D.R. Butler, Y.V.R. Reddy and P. Soman. 1991. Resistance in sorghum to the shoot fly Atherigona soccata: epicuticular wax and wetness of the central whorl leaf of young seedlings. Annals of Applied Biology, 120: 373382.

Patil, S.S., Narkhede B. N. and Barbate, K.K. 2006. Effects of biochemical constituents with shoot fly resistance in sorghum. Agricultural Science Digest, 26: 79-82.

Rao, C.N., and V.P.S. Panwar. 2002. Biochemical plant factors affecting resistance to Chilo partellus (Swinhoe) in maize. Annals of Plant Protection Sciences.

Sharma, H.C., and Nwanze, K.F. 1997. Mechanism of resistance to insect in sorghum and their usefulness in crop improvement. Information Bulletine No. 45. International Crop Research Institute for the Semi-Arid Tropics, Patancheru, pp-56.

Sharma, Manorama, Kapoor, K.N. and Bharaj, G.S. 1993. Effect of seed treatment of sorghum with some new insecticides for control of shoot fly. Crop Res., 11 (1): 90-92

Singh, B.U., Padmaja, P.G. and Seetharama, N. 2004. Stability of biochemical constituents and their relationships with resistance to shoot fly, Atherigona soccata (Rondani) in seedling sorghum. Euphytica, 136: 279-289.

Singh, Y.P., Singh, A.K., Singh, B. and Pandey, N.D. 1989. Susceptibility of sorghum germplasm to Atherigona soccata Rondani. Farm Sci. J., $4(1,2)$ : 28-31.

Sree, P. S., Butler D.R. and Nwanze K.F. 1992. Morphological factors associated with leaf surface wetness. In: Cereal Program Annual Report 1992, International Crop Research Institute for the Semi- Arid Tropics, Patancheru, 502 324, Andhra Pradesh, India. Cereal Program. pp. 24-25.

Taneja, S.L., and R.K. Maiti. 1992. Shoot fly resistance factors. ICRISAT- Annual report, 1992, Cereal Program. pp. 2324.

\section{How to cite this article:}

Patil, S.P. and Bagde, A.S. 2017. Physio-Chemical Resistance Mechanism of Sorghum Genotypes against Shoot Fly (Atherigona soccata) (Rondani). Int.J.Curr.Microbiol.App.Sci. 6(9): 2742-2746. doi: https://doi.org/10.20546/ijcmas.2017.609.337 